\title{
Beyond the Penal Code: The Legal Capacity of Monetary Sanctions in the Corpus of California Law
}

\author{
ANJULI VERMA® AND BRYAN L. SYKES (i)
}

Knowledge about legal financial obligations in American punishment has been largely confined to criminal law and the penal codes of a few states. Yet in the nation's most populous state, California, there is reason to believe that a wider expanse of law beyond the penal code harbors the legal capacity to impose monetary punishments and indebtedness. A legal census of the entire corpus of California's civil and criminal statutory law identifies the presence and distribution of monetary sanctioning statutes within each and across all of the state's twenty-nine legislative code sections. Results show that one in twenty-three statutes in California law concern monetary sanctions and that they are dispersed throughout every section of the legislative code. Our investigation reveals that monetary sanctions are embedded within the broader architecture of state law, and that variations in the structure, as much as the substance, of statutory schemes must figure into empirical and theoretical accounts of racial disparity in the imposition of monetary punishments.

Keywords: legal financial obligations, monetary sanctions, legal capacity, legal census, statutory inequality

Anjuli Verma is an assistant professor of politics at the University of California, Santa Cruz, United States, where she also teaches in the interdisciplinary Legal Studies Program. Bryan L. Sykes is a Chancellor's Fellow, an Inclusive Excellence Term Chair Professor, and associate professor of criminology, law, and society at the University of California, Irvine, United States, with courtesy appointments in the Departments of Sociology and Public Health.

(C) 2022 Russell Sage Foundation. Verma, Anjuli, and Bryan L. Sykes. 2022. "Beyond the Penal Code: The Legal Capacity of Monetary Sanctions in the Corpus of California Law." RSF: The Russell Sage Foundation Journal of the Social Sciences 8(1): 36-62. DOI: 10.7758/RSF.2022.8.1.02. This research was funded by a grant to the University of Washington from Arnold Ventures (Alexes Harris, PI). We thank the faculty and graduate student collaborators of the Multi-State Study of Monetary Sanctions for their intellectual contributions to the project. Partial support for this research came from a Eunice Kennedy Shriver National Institute of Child Health and Human Development research infrastructure grant, P2C HD042828, to the Center for Studies in Demography and Ecology at the University of Washington. This research was also supported by research funds from the Council on Research, Computing and Libraries (CORCL) at the University of California, Irvine. The authors would like to acknowledge the team of research assistants on this project: Marnie Mattei, Hayden Sugg, Nicole Carbonel, Sar Vang, and Nicole Phillips; without their tremendous work and invaluable input, this research would not have been possible. Direct correspondence to: Anjuli Verma, at acverma@uci.edu, Merrill Faculty Annex, 1156 High St., Santa Cruz, CA 95064, United States; and Bryan L. Sykes, at blsykes@uci.edu, 3317 Social Ecology II, Irvine, CA 92697, United States.

Open Access Policy: RSF: The Russell Sage Foundation Journal of the Social Sciences is an open access journal. This article is published under a Creative Commons Attribution-NonCommercial-NoDerivs 3.0 Unported License. 
Legal financial obligations (LFOs) - fines, fees, penalties, assessments, restitution orders, interest, surcharges, and other costs-are routinely imposed on individuals convicted of criminal misdemeanor and felony offenses. Under contemporary mass incarceration in the United States, LFOs breed mass-scale legal debt; in the context of financialization, predatory credit and lending markets, and mass indebtedness among American households by the twenty-first century (Appel, Whitely, and Kline 2019; Pattillo and Kirk 2021; Quinn 2017), LFOs compound crises and consequences for a nation of debtors and populations increasingly reliant on high-interest lines of credit to stave against economic precarity (Graeber 2011; Hyman 2011; Quinn 2019).

Research shows that LFOs, also known as monetary sanctions, in the criminal legal system create barriers to economic self-sufficiency, particularly because people are unable to pay or discharge the sizable legal debts that accrue (Harris 2016; Harris, Evans, and Beckett 2010). LFOs also compound existing socioeconomic inequalities, including racial disparities and selective enforcement of criminal law. The imposition of LFOs has been theorized as an expressive, sociocultural form of punishment that generates and sustains racial and ethnic distinctions in political rationalizations for, and the hyper-concentrated effects of, criminal sanctioning in the United States (Harris, Evans, and Beckett 2011).

More recently, insights from economic sociology about the rise of late-modern financialization and social organization of credit and debt under neoliberalism have been synthesized to deepen theoretical understandings of LFOs in wider markets that demand discipline and control through "coercive financialization" (Pattillo and Kirk 2021) and the category of indebtedness. Moreover, from a political economy perspective, LFOs have come into even starker view as predation (Page, Piehowski, and Soss 2019) beyond punishment, and as a phenomenon consistent with the predatory social processes by which targeted, systematic divestment, extraction, and dispossession are legally legitimated by producing a criminal category in law that authorizes social domination (see Ward 2015). ${ }^{1}$

Yet even as this burgeoning scholarship has expanded theoretical conceptualization of monetary sanctions in the United States, much of our empirical knowledge about state power and the specific legal power to impose LFOs is restricted to their statutory presence in criminal law and penal codes that specify and sanction punishments for crimes defined as such. If LFOs are socially productive sanctions beyond their criminological and legal definition, then whether they are understood as sociocultural expressions of punishment (Harris, Evans, and Beckett 2011), as economic tools of neoliberal social control in an age of financialization (Pattillo and Kirk 2021; see also Sykes et al. 2022, this volume), or as the latest legal cover for human predation and social domination (Page, Piehowski, and Soss 2019), there is reason to believe that a wider expanse of legislative codes harbor and levy fines and fees across multiple regulatory domains beyond the Penal Code (Bannon, Nagrecha, and Diller 2010; Beckett and Murakawa 2012; DOJ 2015; Evans 2014; Friedman and Pattillo 2019; Gordon and Glaser 1991).

In this article, we investigate the extent to which seemingly distal legislative code sections impose similar forms of punishment that extend beyond the Penal Code of the State of California. We ask how the scale, scope, and distribution of codified monetary sanctioning statutes across the corpus, or body, of law create the legal capacity for regulatory agencies to exercise state power in selective ways that stand to produce racial disparity as a social fact in the imposition of LFOs. We conceptualize legal capacity as the power that law produces to have social effects, including social inequality. Put in terms of sociolegal scholarship (see, for example, Gould and Barclay 2012), legal capacity is the power produced by law-on-the-books that makes possible the range of social effects, including disparate effects, that can be observed in practice and implementation as law-in-action (see Smith, Thompson, and Cadigan 2022).

We draw on the California Legislative Code

1. Geoff Ward $(2015,1)$ describes these predatory social processes as "the slow violence of state organized race crime." 
as a source of data to assess the state's legal capacity for monetary sanctions in statutory law. By treating the California Legislating Code as a window into various domains of life, each bounded by specific legal parameters and bodies of law-including fine and fee provisionsthat can be activated by law enforcement personnel and other agencies, our analysis shows that monetary sanctioning statutes are spread across each of California's twenty-nine legislative code sections, thereby levying some form of legal financial obligation on individuals convicted of a crime, and regulating budgetary allocations for the revenues generated. We also assess the prevalence, distribution, relative concentration, and whether statutory disparities exist in the location of LFOs as codified across legislative code sections. Findings from this analysis speak to the importance of understanding how "statutory inequality" (Friedman and Pattillo 2019) forges social inequality. Findings also highlight the need to reconceptualize the locus of legal power to impose monetary sanctions that breaks civil-criminal binaries to reveal the totality of legal impacts - and the systemic nature of compounding social inequality in monetary sanctions-as economic barriers to reentry and reunification across multiple spheres of social life.

This article examines how the architecture of law, built in part by the distribution of monetary sanctions within and across legislative codes, matters for thinking about the imposition of LFOs and the theoretical and empirical social inequality made possible. Based on our findings from a legal census of the entire California legislative code, we argue that the racial disparities observed within the state's criminal legal system have their antecedents in legal capacity - the prevalence and unequal distribution of monetary sanctioning statutes throughout legislative code sections that confer the power to impose civil, criminal, or some hybrid of civil-criminal financial penalties for offenses when state power is exercised, and exercised selectively, by specific agencies tasked with regulating populations and enforcing laws. We find that, overall, one in twenty-three statutes within the California legislative code include rules about monetary sanctions and that these statutes are dispersed across every section of the legislative code. Findings speak to the importance of moving beyond civil-criminal binaries in research and policy interventions to reveal statutory inequalities that inscribe and structure observed social, economic, and racial inequalities in monetary sanctions.

\section{THEORETICAL FRAMEWORK: THE CIRCUITRY OF MONEY, PUNISHMENT, AND LAW}

Based on ethnographic and qualitative interview data collected in the state of Washington, Alexes Harris $(2016,99)$ observes that "LFOs are imposed and enforced in varying and uneven ways" resulting in what she calls a "punishment continuum," which refers to the scale and severity of not just the dollar amounts of monetary sanctions imposed, but also the degree of monitoring and sanctioning for nonpayment by judges and clerks across the state's county courts. "Divergent interpretations of state law" by county court prosecutors, defense attorneys, judges, and clerks are explained through a process whereby LFO statutory interpretationsand thus the scale and severity of their application-diverged as a function of differences in the "local "culture of punishment" across Washington's thirty-nine counties (100). Therefore, "because county judges interpret and apply the state law guiding monetary sanctions in very different ways, counties can be understood in relation to their position on a punishment continuum that is determined in part by the average LFO imposed on defendants" (110). But only in part. Harris's analysis also begins to take account of particular mechanisms by which differential assessments of people who are defendants in criminal court and their willingness and ability to pay LFOs are animated and rationalized in the context of the same legal text and statutory scheme for LFOs under Washington state law.

Harris $(2016,120)$ argues that "the application and enforcement of monetary sanctionsspecifically, the different ways in which legal concepts are interpreted and applied-vary according to the local culture of punishment. A county's punitive orientation does not directly map onto the size of the LFOs it assesses." In other words, not just the amount of LFOs in dollars (and, also, presumably, the number and 
prevalence of LFO impositions), but "instead, how it assesses, monitors, and enforces LFOs more nearly describes its position on the punishment continuum" (120, emphasis added). As referenced by Harris (120), David Garland (1990, 283) observes that "in a sense, each institutional site gives rise to a distinctive world of its own with its own characters and roles, statuses and rule-governed relationships-as anyone who moves from one setting (or jurisdiction) to the other will readily experience."

Other than what the content of these LFO statutes come to say, where those statutes are situated within the varied terrain and topology of law-how they are classified and crossclassified, located and colocated, according to the historically construed indexical vagaries of legal codes-also stands to engender any LFO statutory scheme a "world of its own" (Garland 1990, 283). Depending on the particular legal code, we can also ask whether LFO statutes might have distinctive worlds of their own that are configured and contoured by the architecture of their particular legal creation and location.

In this study, we conduct a form of censustaking that enumerates and maps the terrain of LFOs in a statutory universe of legal codes. Like previous attempts to conduct a comprehensive accounting of the laws imposing the full breadth of "collateral consequences" in the U.S. criminal legal system (Collateral Consequences Resource Center 2019; National Clean Slate Clearinghouse 2015-2021; National Inventory of Collateral Consequences of Conviction 2020), which Joshua Kaiser $(2016,127)$ argues ought be understood and named as "extra-legal punishments" rather than as mere "consequences" that are "collateral" to legal punishment, the census we undertook was motivated by a desire to uncover the "hidden sentences" of money and punishment.

In the case of LFOs, we contend that it is, more specifically, the legal capacity to produce the (monetary) sanction that risks remaining hidden in what Katherine Beckett and Naomi Murakawa $(2012,222)$ call the "shadow carceral state"-first, due to the "inconspicuousness" (Kaiser 2016, 165) of LFOs in fields of view trained on criminal law in the Penal Code and, second, due to the "scope" (156) and "dispersion" (157) of their imposition on people who may have never been incarcerated, or even convicted of a felony. We contend that LFOs are inconspicuous because monetary sanctioning statutes may be codified elsewhere and outside of criminal law, beyond the Penal Code, and thus may never be found by researchers and reformers focused on criminal sanctioning statutes and the imposition of LFOs in criminal law (for example, on the problem of data gaps in the state of California, see Rabinowitz, Weisberg, and Pearce 2019). The scope and dispersion of LFO statutes across the corpus of law implicates the legal capacity for state power to impose monetary sanctions on a vast but hidden population of people who may never have been incarcerated or convicted of a felony, but remain under lengthy periods of correctional supervision (see Natapoff 2018; KohlerHausmann 2018; Beckett and Murakawa 2012).

Brittany Friedman and Mary Pattillo (2019, 173) conceptualize "statutory inequality" as a defining feature of monetary sanctioning in Illinois state law, which "legally authorizes further impoverishment of the poor, thereby increasing inequality." We build on Friedman and Pattillo's $(2019,175)$ crucial observation about the role of statutory inequality in mutually constituting wider social inequality by inscribing penal indebtedness for poor people into law on the books, and we deepen this observation by focusing "on how what law allows" can also open a "window into the social, cultural, and political moods about criminals and punishment" that "precedes the unequal outcomes" documented in the literature (see, for example, Harris, Evans, and Beckett 2010).

We draw attention to how the structure of law itself, and the presence and arrangement of monetary sanctions statutes within that structure, facilitates and furthers social inequality through statutory inequality. Specifically, we contend that statutory inequality makes possible social inequality because of $l e$ gal capacity - the prevalence and unequal distribution of monetary sanctioning statutes throughout legislative code sections that contain the power to impose civil, criminal, or some hybrid of civil-criminal financial penalties for offenses when state power is exercised, and exercised selectively, by specific agencies tasked with regulating populations and enforc- 
Figure 1. Theoretical Model of the Circuitry of Legal Capacity to Produce Racial Disparities

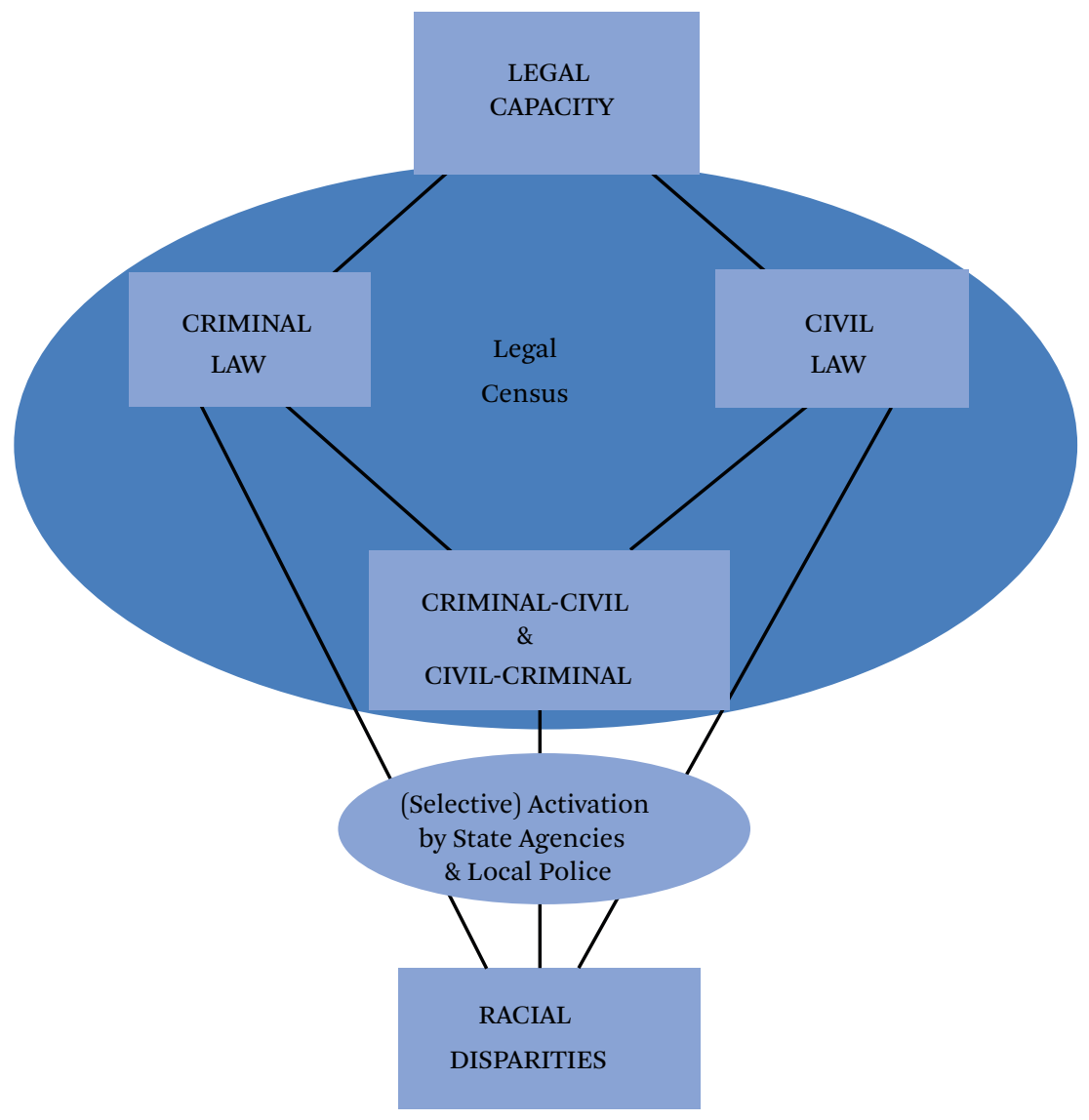

Source: Authors' conceptualization based on review of relevant literature and theoretical frameworks.

ing laws. This legal capacity can be activated when particular statutes within specific code sections are selectively applied by state agents to disparate subgroups of the population, thereby contributing to racial and economic inequality in particular sociolegal outcomes. Therefore, mapping the composition and distribution of LFO statutes across and within legislative code sections establishes interdependences, interconnections, and mutual referents that form what is more like a circuitry of power with multiple trigger points and levers than a linear code of law, which we propose, theoretically, functions with nonlinear effects and compounding legal risks as individuals encounter the state in multiple domains of social life, law, and legal regulation.
Figure 1 displays the theoretical circuitry of legal capacity to generate racial disparities. Codified state statutes governing monetary sanctions, and their cross-classifications and synergies within disparate nodes of the state's legislative code sections, locate punishment and penalizing powers within both criminal and civil law. However, the varying size, scope, and dispersion (Kaiser 2016) of legal capacity within each code section is an artifact of the uneven legislative terrain wherein these powers are created. Assumptions that the location of monetary sanctioning statutes are limited to criminal law and penal codes, contributes to the possible concealment, or inconspicuousness (Kaiser 2016), of civil-criminal hybrids, given that some civil offenses can result in 
criminal charges and some criminal charges can lead to civil suits (see also Beckett and $\mathrm{Mu}$ rakawa 2012). Only through a legal census of the legislative code can this hybridity be revealed, with particular implications for the study of monetary sanctions and racial disparities therein. The exercise of state power to punish and to penalize people, as well as corporate persons and entities, stands to produce racial disparities in monetary sanctions when regulatory agencies selectively activate, or selectively avoid activating, the legal capacity of specific statutes within legislative code sections.

\section{The Case and Corpus of California Law}

The organization of California law provides a unique opportunity to explore how legal capacity is created, structured, and sustained to produce the state's power to regulate multiple domains of social life. A legal census is necessary to reveal the totality of legal capacity, which is what the California Law Revision Commission's Committee on Revision of the Penal Code undertook; as of January 2020, the commission set out to enumerate and evaluate the statutes, specifically within the Penal Code, that produce and exacerbate well-known racial disparities within the state's criminal legal system (Committee on Revision of the Penal Code 2021). ${ }^{2}$

In California, the body of governing statutory law is known as the California Legislative Code. The California Legislative Code is a collection of state laws passed by the California State Legislature and organized by subject area into categorical sections of code, each with divisions, parts, titles, chapters and sections. Unlike common law systems, in which law is derived from judicial decisions instead of from statutes, civil law legal systems place a stronger reliance on legislative statutes and ordinances for applying and interpreting law. However, under common law legal systems, judicial interpretation in case law is premised on analogical reasoning and proceeds according to precedent, or by applying the precedent set by higher courts in similar cases. The task of judicial in- terpretation in civil law legal systems relies more heavily, however, on the legislative text of applicable statutes rather than on previous court rulings as precedent, often using research into the legislative history of statutes to gauge legislative intent.

Common law (derived from the English common law system) predominates in nearly all U.S. states; only Louisiana structures its state legal system based on civil law (retaining reliance on the French Napoleonic Code). However, California is one of only three U.S. states to have subjected its body of common law to legal codification - that is, a systematic code of statutes classified and arranged by category into discrete code sections. Legal codification is a distinctive feature of California law for two reasons: first, besides any variations that might be found in the substance of LFO statutes across U.S. states, the structure of the body (its corpus) of law in California departs substantially from that of nearly all other U.S. states, which, but for Texas and New York, have resisted codifying their bodies of common law. Second, the embodiment of legal codification in California implicates the context and structure in which statutes are embedded and organized in the larger body of state law, including legislative history and intent, which become explicit, central considerations in how courts interpret the meaning of state statutes. Legal codes form the basic anatomy of law's textual "body," and each statute enacted by the state legislature is classified into one of the legal codes, such that the specific legal capacity created by and contained in any given statute will have a specific and identifiable location, function, and form (see Field 1890).

Tracing the true dimensions of legal capacity is impossible without conducting a firstorder legal census. Just like a census to count, locate, and record salient characteristics of all the members of a population, precisely because some types and groups would otherwise remain systematically hidden from view and rendered invisible in the count (Pettit 2012; Pettit and Sykes 2015), a census of the entire state leg-

2. California Government Code (CA Govt Code) § 8290.5 (2020). 
islative code is the imperative starting point for any systemic analysis, empirically and theoretically, of how state statutes crafted by policymakers lay the groundwork for criminal legal practices that perpetuate racial and economic inequality. Taking a legal census is necessary to capture the universe of monetary sanctioning statutes and thus the corpus of LFO legal capacity. Here, the schema of punishment takes particular form in the shape of its embodiment in the unequal distribution of monetary sanctioning statutes in California's legislative code. The theoretical value is that a legal census methodologically approaches the question with no a priori assumptions.

Indeed, the legal census starts from a theoretical premise, which it investigates empirically, that part of the nature of legal capacity is the legal circuitry between and across the criminal and civil that closes off the power it holds from view in the shadowy map of precisely where the power to punish resides and is sustained in the carceral state (see figure 1) (Beckett and Murakawa 2012). Knowledge gained through a legal census of the composition and contours of legal capacity, available to be activated monetarily as punishment, provides researchers and reformers with insight into a crucial existing parameter for state action and discretionary practice among state agents. For instance, a legal census of state law concerning LFOs could inform a range of legal and policy implementation studies about how judges and other practitioners in the criminal legal system construct the "ability" or "willingness" of people before them to pay imposed LFOs, as well as their eligibility as subjects of legal indebtedness (Bing at al. 2022, this volume; Fernandes, Friedman, and Kirk 2022, this volume; Sykes et al. 2022, this volume). The policy implication is that attention to this circuitry of state power contained in the legal capacity that stands ready to be activated, applied, and invoked is that we need to understand how and where the power to sanction monetarily is activated, and the locations of triggers for activation within that circuitry that unleash the state power to impose LFOs where, when, and on whom, from well beyond the Penal Code. Knowing how the circuit runs becomes the map for tracing high-value pres- sure points for reform, and even discovering circuit breaks.

Notably, the nation's next most populous state after California (Census Bureau 2021), Texas, has already undertaken a legal census of its corpus of law in a Study of the Necessity of Certain Court Costs and Fees in Texas (State of Texas 2014; Dahaghi 2017). However, that census was incomplete insofar as the composition and distribution of monetary sanctioning statutes across and within each of the state's legal code sections that govern particular domains of social life was not coded and counted. This incomplete census in Texas thus leaves open important theoretical and empirical questions about legal capacity that we can explore in the case of California. Although the empirics in California will differ, the ability to conduct a complete census that captures both the compositional and distributional dimensions of monetary sanctioning statutes enables researchers and policymakers more broadly who are concerned with racial disparities to understand the location and concentrations of state power and the legal capacity to impose LFOs across their corpus of law (for an example of research investigating the real effects of attempts to reform LFOs in criminal law or policy, see Huebner and Giuffre 2022, this volume). Thus our empirical inquiry seeks to establish the characteristics and attributes of monetary sanctioning statutes distributed and dispersed across the California body of law.

\section{DATA AND METHODOLOGY}

Between February and May of 2016, a team of seven researchers systematically coded each section of the California Legislative Code (see table 1). Our original dataset includes information on whether a statute concerns fines, fees, assessments, or restitution; LFO maximum and minimum amounts; whether the statute imposes incarceration; and the classification of the offense as a misdemeanor or felony. Other contextual details about the statute were also recorded, such as the year of its enactment or amendment (for the full codebook with variable list, abbreviations, and descriptions, see table A1).

First, coders were instructed to use the California Legislative Information (CLI) website as 
Table 1. California's Twenty-Nine Legislative Code Sections

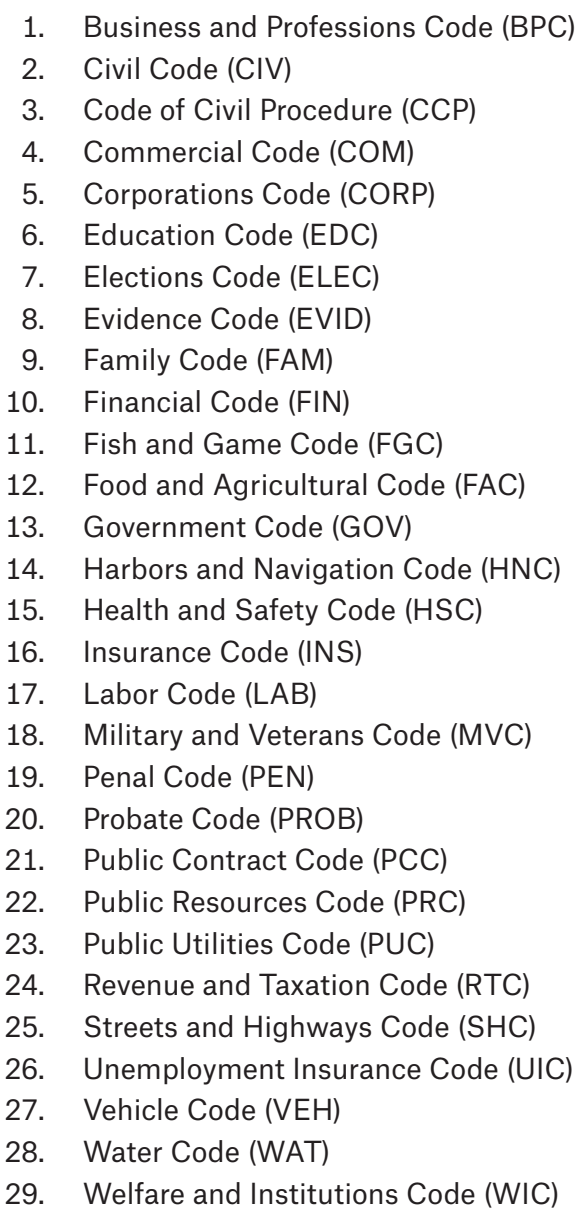

Source: California Legislative Information, https://leginfo.legislature.ca.gov/faces/codes.xhtml (accessed August 4, 2021).

the official and up-to-date source of all statutes within the legislative code. ${ }^{3}$ Each code section was independently reviewed by two researchers, and each statute within the code section was classified and catalogued by statute number if it concerned LFOs. In our coding scheme, different types of LFOs were not coded as mutually exclusive measures for any given statute; for example, one statute can simultaneously impose fines, fees, enhancements, and surcharges, and thus was coded as YES=1 for all relevant measures. The total count of statutes concerning LFOs was calculated by summing the number of observations entered and catalogued by statute number for each and all of California's twenty-nine legislative code sections. Although the attributes coded for each observation were not mutually exclusive, each statute coded as concerning LFOs within a code section records an independent observation. ${ }^{4}$

Second, although the emphasis of this study is on the imposition of LFOs in the criminal

3. California Legislative Information, “California Law, Code Search," https://leginfo.legislature.ca.gov/faces /codes.xhtml (accessed September 1, 2021).

4. Each observation of a statute concerning LFOs was entered separately in its own row and coded according to the unique identifier of the statute number assigned to it, allowing for an enumeration of the total number of independent statutes concerning LFOs reported in summary statistics. 
legal system-that is, LFOs imposed by the state on people charged and convicted of criminal offenses-certain LFOs in the civil context were also coded. Statutes that impose a civil LFO that is owed to the state by an individual for a civil violation are also coded, given that these financial penalties also function a form of punishment, or "punitive civil sanctions" (see, for example, Mann 1980; Coffee 1992; Kaiser 2016). However, statutes that impose administrative fees for the mere use of state services in the civil context (such as photocopying documents or state-administered medical care) are not coded because they are not imposed to function precisely as punishment in civil law.

The legal census we conducted in the state of California aimed to identify all statutes concerning the imposition, administration, collection, and enforcement of legal financial obligations. Consistent with the coding methodology used across state field sites in the multiyear, multistate research project (Harris, Pattillo, and Sykes 2022, this volume), once a statute or administrative rule was identified, we coded it for thirty-one characteristics, such as if nonpayment triggered license suspension, if it was eligible for referral to private collections, or if interest accrued after the due date (see table A1). We tracked basic information, such as the statute number, code section, whether it concerned a fine or a fee, the year it was passed, whether it imposed mandatory or discretionary monetary sanctions or sanctioning terms, and verbatim text of the observed statute itself.

Consistent with the Multi-State Monetary Sanctions Study research team as a whole, the "ostensibly simple exercise of establishing a research design offers important insight into the challenges of studying, and thus intervening in and possibly reforming, any criminal legal processes, much less the system of monetary sanctions" (Harris, Pattillo, and Sykes 2022, this volume, p. 9). Our coding scheme seeks to account for how the codification of California state statutes may blur the distinction between civil and criminal monetary sanctions associated with punishment.

Third, a SAS program was written to exam- ine intercoder reliability by identifying differences in recorded statutes for research dyads assigned to a code section. Where differences were observed, a third independent researcher verified and coded the legislative section to resolve discordances. Remarkably, 97.7 percent of statutes were coded reliably between the two independent researchers.

The statutes coded by the research team indicate the total number of statutes concerning LFOs, which represents the overall size of legal capacity for LFO imposition across all sections of the California legislative code. To obtain denominators, we relied on the California Statutes and Court Rules Database and Westlaw Next Online Legal Research. Westlaw Next is an online proprietary database that captures and catalogues legal statutes, their dates of enactment, amendment, and repeal for more than sixty countries. ${ }^{5}$ We use Westlaw Next to obtain the total number of statutes, which we use as the denominator for each legislative code section, to construct percentages of LFOs within each code section, as well as across all sections, of the California legislative code. We used the last date of coding (June 8, 2016) as the effective date of coding. Because we had coders enter the last numbered statute in each legislative code section listed on the CLI website, and we were able to confirm that the last numbered statute on the CLI website corresponds to the last statute listed in Westlaw Next, we were able to then systematically determine the Westlaw Next total count of statutes within each California legislative code section.

We construct the proportion of LFO statutes within a code section to report the relative prevalence of LFO statutes as a subpopulation within each of the twenty-nine code sections by dividing the number of LFO statutes within that section by the total number of statutes per the Westlaw Next count described. We also summed both the total number of LFO statutes and the Westlaw Next count of all statutes in total across all code sections to estimate the total prevalence, or density, and the overall distribution of monetary sanctions that populate the whole of California legislative statutes. We

5. Westlaw Next Online Legal Research, https://legal.thomsonreuters.com/en/products/westlaw. Accessed September 1, 2021. 
then delve into the density, distribution, and dispersion of specific characteristics, features, and types of observed LFO statutes themselves as a compositional dimension of this legal census-taking to estimate the size, subgroups, and structure of the population of LFO statutes in California law as an exploratory data analysis of the legal capacity to punish through monetary sanctions. This secondary dimension of analysis enables us to consider the composition and dispersion of different characteristics and kinds of LFOs, in addition to size, density, and distribution as relevant parameters for identifying and validly describing the legal capacity to punish that resides in California statutory law. Further, the dispersion of variable characteristics, features, and kinds of LFO statutes themselves are elements of the circuitry of this legal capacity, with different densities, distributions, and flows of power within and across the spans of California law, as codified in twenty-nine code sections.

\section{RESULTS}

We now turn to the first set of results, concerning prevalence and distribution, in which we report the total number of LFO statutes coded across all California legislative code sections and the overall proportion of LFO statutes in the entirety of California statutory law. We also report counts for each of the twenty-nine legislative code sections and, in turn, construct proportions to estimate the prevalence of LFO statutes relative to the total number of statutes within each code section.

\section{Prevalence and Distribution of LFO \\ Statutes in California Law}

Table 2 presents the total number and percentage of statutes concerning legal financial obligations for each section of the California legislative code. Of the 165,607 statutes in the legislative code, 7,043 are LFO statutes, with each code section including at least one statute concerning fines, fees, restitution, or assessments. This results in approximately one in twenty-three LFO statues (a prevalence of 4.3 percent) across all twenty-nine code sections. While it is unknown whether 4.3 percent is relatively low or high-given that complete censuses of legal codes in other states have not been conducted-our enumeration counts and categorizes the presence of monetary sanctioning statutes in other areas of law often ignored in the study of money and punishment and thus can serve as a baseline for future comparisons.

Additionally, we find that each code section

Table 2. Number and Prevalence of Statutes Concerning Legal Financial Obligations, by California Legislative Code Section, June 2016

\begin{tabular}{lccc}
\hline Legislative Code Section $(n=29)$ & $\begin{array}{c}\text { Number of } \\
\text { LFO Statutes }\end{array}$ & $\begin{array}{c}\text { Total Number } \\
\text { of Statutes }\end{array}$ & $\begin{array}{c}\text { Prevalence of } \\
\text { LFO Statutes (\%) }\end{array}$ \\
\hline Total & 7,043 & 165,607 & 4.25 \\
Penal Code (PEN) & 1,356 & 7,168 & 18.92 \\
Vehicle Code (VEH) & 635 & 4,615 & 13.76 \\
Labor Code (LAB) & 335 & 3,240 & 10.34 \\
Business and Professions Code (BPC) & 670 & 8,295 & 8.08 \\
Fish and Game Code (FGC) & 218 & 3,024 & 7.21 \\
Health and Safety Code (HSC) & 664 & 9,484 & 7.00 \\
Evidence Code (EVID) & 35 & 588 & 5.95 \\
Revenue and Taxation Code (RTC) & 550 & 9,309 & 5.91 \\
Harbors and Navigation Code (HNC) & 82 & 1,703 & 4.82 \\
Food and Agricultural Code (FAC) & 407 & 9,564 & 4.26 \\
Government Code (GOV) & 354 & 9,274 & 3.82 \\
Civil Code (CIV) & 224 & 6,419 & 3.49 \\
Military and Veterans Code (MVC) & 59 & 1,777 & 3.32 \\
Welfare and Institutions Code (WIC) & 324 & 9,885 & 3.28 \\
& & & (continued)
\end{tabular}


Table 2. (continued)

\begin{tabular}{lccc}
\hline Legislative Code Section $(n=29)$ & $\begin{array}{c}\text { Number of } \\
\text { LFO Statutes }\end{array}$ & $\begin{array}{c}\text { Total Number } \\
\text { of Statutes }\end{array}$ & $\begin{array}{c}\text { Prevalence of } \\
\text { LFO Statutes (\%) }\end{array}$ \\
\hline Financial Code (FIN) & 200 & 6,312 & 3.17 \\
Unemployment Insurance Code (UIC) & 54 & 1,778 & 3.04 \\
Water Code (WAT) & 230 & 9,701 & 2.37 \\
Family Code (FAM) & 43 & 1,910 & 2.25 \\
Corporations Code (CORP) & 84 & 4,399 & 1.91 \\
Elections Code (ELEC) & 88 & 5,527 & 1.59 \\
Public Resources Code (PRC) & 127 & 9,243 & 1.37 \\
Public Utilities Code (PUC) & 97 & 8,764 & 1.11 \\
Education Code (EDC) & 86 & 9,332 & 0.92 \\
Insurance Code (INS) & 49 & 5,757 & 0.85 \\
Commercial Code (COM) & 6 & 801 & 0.75 \\
Code of Civil Procedure (CCP) & 30 & 5,215 & 0.58 \\
Public Contract Code (PCC) & 8 & 1,923 & 0.42 \\
Streets and Highways Code (SHC) & 19 & 6,594 & 0.29 \\
Probate Code (PROB) & 9 & 4,006 & 0.22 \\
\hline
\end{tabular}

Source: Authors' tabulation based on California Legislative Information (2021) and Westlaw Next (2021).

Figure 2. Percentage of LFO Statutes in California's Penal Code, Relative to All Other California Legislative Code Sections

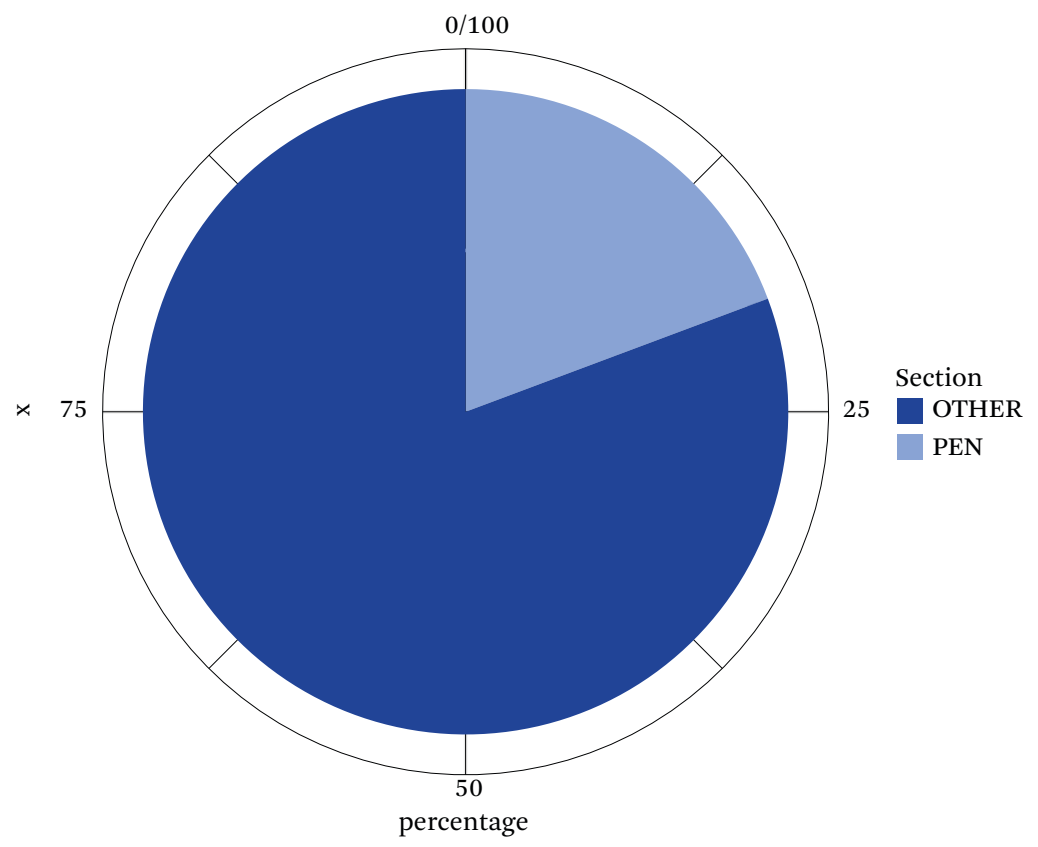

Source: Authors' tabulation from original coding of statutes from California Legislative Information, https://leginfo.legislature.ca.gov/faces/codes.xhtml (date of last coding June 8, 2016) and total counts of statutes from Westlaw Next Online Legal Research, “California Statutes \& Court Rules” database search queries (effective date: June 8, 2016), https://legal.thomsonreuters.com/en/products/westlaw. Accessed September 1, 2021. 
imposes some form of legal financial obligation on individuals found in violation of the law or regulates budgetary allocations for the revenues generated. The Penal Code has the highest percentage of LFO statutes (18.9 percent), whereas the Probate Code has the lowest $(0.22$ percent). Second to the Penal Code, LFOs are most prevalent in the Vehicle Code (13.8 percent); the Labor Code comes third (10.3 percent), which has been ignored in empirical research on LFOs and in conceptualizing monetary sanctions and their implications for socioeconomic inequality.

Table 2 demonstrates that the Penal Code has the highest prevalence of monetary sanctions, but these findings can be interpreted in other ways. Figure 2 summarizes the percentage of monetary sanctions in the California legislative code. This figure shows that, relative to all other code sections, the Penal Code accounts for only about one-fifth of all LFOs in California law, with four out of five monetary

Figure 3. Distribution of LFO Statutes Across California's Twenty-Nine Legislative Code Sections

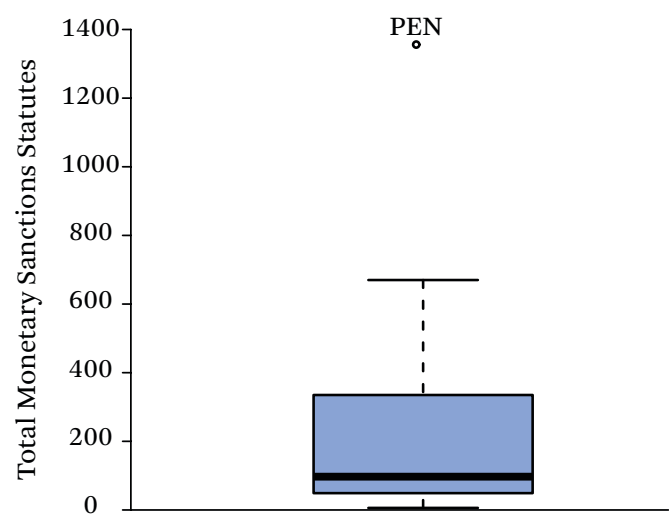

Source: Authors' tabulation based on original coding of statutes from California Legislative Information, https://leginfo.legislature.ca.gov /faces/codes.xhtml (date of last coding June 8, 2016) and total counts of statutes from Westlaw Next Online Legal Research, "California Statutes \& Court Rules" database search queries (effective date: June 8, 2016), https://legal.thomsonreuters .com/en/products/westlaw. Accessed September $1,2021$. sanctioning statutes in other code sections. This finding is important because it draws attention to the otherwise hidden statutory locations of legal capacity for LFOs that can be activated, if, when, and where needed by the state.

Figure 3 summarizes the dispersion of statutes across the twenty-nine code sections. This boxplot illustrates that the median number of LFO statutes is 97 and the interquartile range is 286 (the difference between the 75th percentile and the 25 th percentile is 286 LFO statutes). The 5th percentile has 8.4 LFO statutes, and the 95th percentile has 667.6. Yet, even among these statistics, the Penal Code is a considerable outlier in that the number of monetary sanctions in this code section is more than two standard deviations away from the 95th percentile.

\section{Composition and Substance of \\ LFOs in California Law}

These results bring the legal corpus of monetary sanctions into distributional relief, revealing that a constellation of statutes concerning LFOs extends well beyond the state's Penal Code. Having shown the prevalence of LFO statutes within each of legislative code sections, as well as their relative distributions across code sections in the whole of California's statutory law, we now move to a deeper analysis of the content and composition of LFOs found across the wide range of code sections and consider the array of substantive differences revealed by displaying both distributional and compositional dimensions of variation.

Figure 4 presents a heatmap of the coded monetary sanctioning statutes and their characteristics across the twenty-nine code sections. The sections are sorted along the $x$-axis of figure 4 in descending order based on the prevalence of LFO statutes (percentage) reported earlier (in table 2), starting left from the Penal Code (PEN), with the highest prevalence (18.9 percent), and ending right, with the least prevalent, Probate Code (PROB) (0.22 percent). The $y$-axis empirically maps the size, composition, and dispersion of the legal capacity to punish through monetary sanctions pertaining to thirty-one LFO characteristics (for descriptions, see table A1). The proportion of each characteristic for all monetary sanctioning stat- 


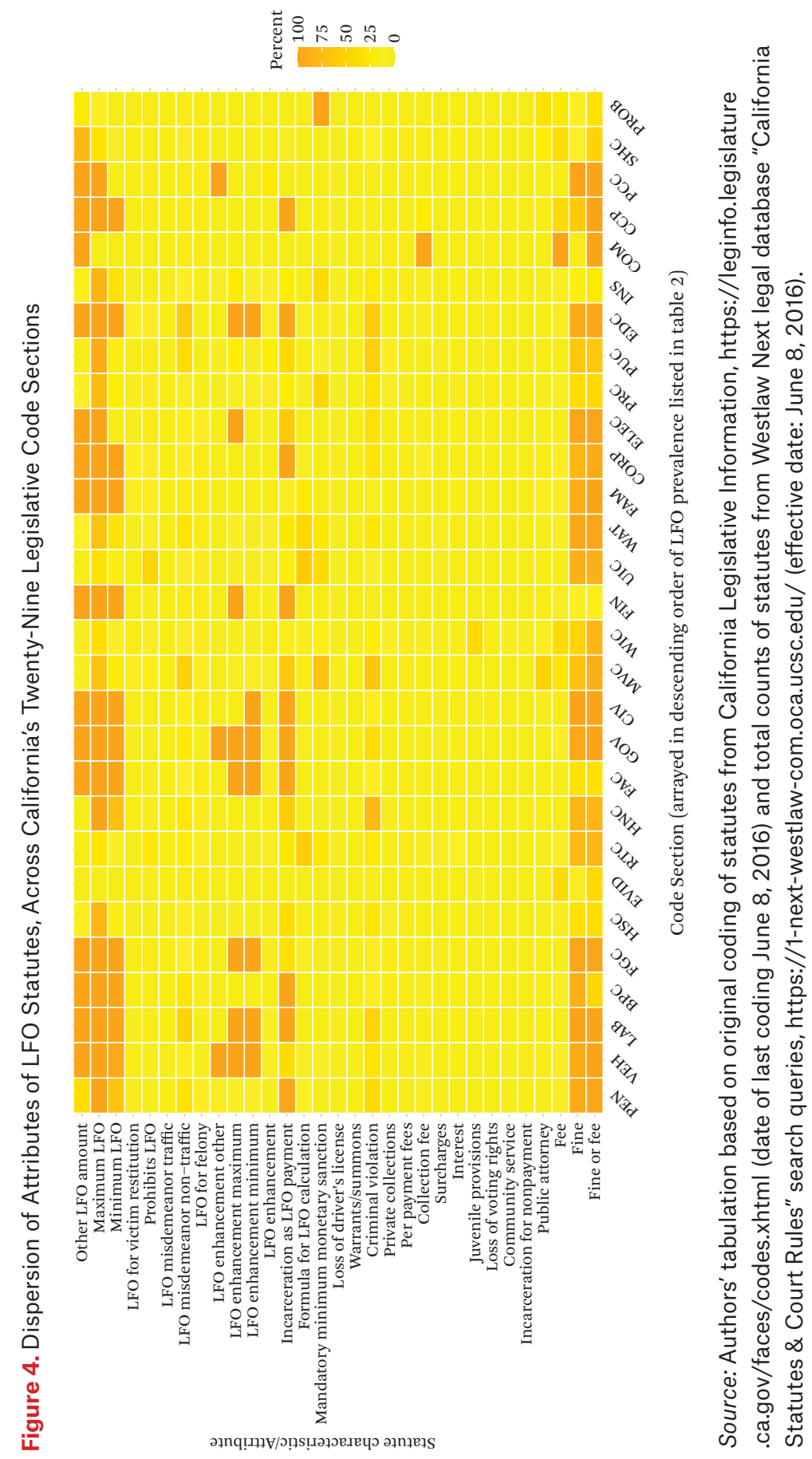


utes within that section is represented by a shaded gradient: the lightest shade represents the lowest percentage (no density, 0 percent), and the darkest shade the highest percentage (or the most intense density, 100 percent). Percentages between these two bounds are represented by the shaded gradients, as you move from one extreme to the other. Only by examining these thirty-one compositional attributes of LFOs, including their relative concentrations and dispersions across the twenty-nine legislative code sections, do we begin to observe a more complete census of the legal capacity for monetary sanctions as punishment in California law.

Several findings come into relief based on figure 4 . First, the heatmap clearly displays that monetary sanctioning statutes are largely composed of fines and fees, as well as specified mandatory minimum and maximum LFO amounts. It is also apparent that incarceration can be used as a form of LFO payment, and that the legal capacity for incarceration as LFO payment is dispersed across many code sections. A less obvious, but no less important, observation is that the prohibition of LFOs exists to constrain the legal capacity to impose LFOs in more than half of the code sections, including the Penal Code (1.3 percent). ${ }^{6}$ Also, we see that LFO enhancements (specifying enhancement minimums, maximums, and other amounts) appear at high intensities across many code sections.

The second main finding is that, although the Penal Code has the highest prevalence of monetary sanctions (see table 2), the Penal Code does not appear to be unique in the composition of its legal capacity to impose, collect, administer, and enforce monetary sanctions. By vertically examining the Penal Code column, in relation to other code sections, the dispersion and concentration of LFO attributes (arrayed horizontally) appears to show that the Penal Code is less of an outlier in the dispersion of compositional attributes relative to other sections; on this dimension the Penal Code appears not to be markedly dissimilar. This observation suggests that even the code sections that contain relatively few monetary sanctioning statutes relative to the Penal Code (see table 2) may have compositional dispersion that is just as punitive in their legal capacity.

To more closely consider implications of the heatmap in figure 4, we now home in on some exemplars that demonstrate how the composition and dispersion found in this legal census theoretically produces the very elements and circuitries of legal capacity through which the power to punish may flow selectively and disproportionately. Table 3 presents four exemplary cases that underscore the power of legal capacity to theoretically produce racial disparities. We begin by observing four social facts. First, there are racial disparities in arrests for driving on a suspended license (Committee on Revision of the Penal Code 2021). Second, there are racial disparities in employment among people with criminal records (Western and Pettit 2000, 2005; Pager 2003; Pager, Bonikowski, and Western 2009). Third, there are racial disparities in felony arrests and convictions for possession of a controlled substance (Mooney et al. 2018; Shannon et al. 2017). Fourth, there are racial disparities in foster care placement (Needell, Brookhart, and Lee 2003; Child Welfare Information Gateway 2020). Each of these social facts, despite differences in the type of occasion for state intervention, is triggered by a regulatory agency (or agencies) with the power to enforce or, in the case of civil suits, invoke laws on the books. Yet these agencies have such power by virtue of the legal capacity embedded within the broader circuitry of the legislative code (see figure 1) and how LFO statutes are distributed across code sections that govern different domains of social life (see table 2 and figure 4 ).

Consider, for example, a job applicant who is forced to disclose a previous arrest record,

6. Three code sections with the highest densities of statues prohibiting LFOs are visible to the naked eye: Unemployment Insurance (UIC), 45.2 percent; Revenue and Taxation (RTC), 25.6 percent; and Military and Veterans (MVC), 16 percent. The others are less visible (less than 16 percent): Corporations (CORP), Evidence (EVID), Food and Agricultural (FAC), Family (FAM), Finance (FIN), Harbor and Navigation (HNC), Health and Safety (HSC), Penal (PEN), Public Resources (PRC), Vehicle (VEH), Water (WAT), and Welfare and Institutions (WIC). 
Table 3. State Legal Capacity to Produce Racial Disparities as Observed Social Facts: Four Exemplars

\begin{tabular}{|c|c|c|c|}
\hline Social Fact & $\begin{array}{l}\text { Triggering } \\
\text { Agency }\end{array}$ & $\begin{array}{l}\text { Type of } \\
\text { Offense }\end{array}$ & Legal Capacity \\
\hline \multirow{5}{*}{$\begin{array}{l}\text { 1) Racial Disparities } \\
\text { in Arrests for } \\
\text { Driving on A } \\
\text { Suspended License }\end{array}$} & \multirow[t]{15}{*}{ Local Police } & \multirow{15}{*}{$\begin{array}{l}\text { Criminal } \\
\text { (mis- } \\
\text { demeanor) }\end{array}$} & 1) Penal Code $\S 1464$ (penalty assessment) \\
\hline & & & 2) Penal Code $\S 1465.7$ (criminal surcharge) \\
\hline & & & 3) Penal Code $\S 1465.8$ (Court operations assessment) \\
\hline & & & 4) Government Code $\S 70372$ (Court construction) \\
\hline & & & 5) Government Code $\S 76000$ (County fund) \\
\hline (Committee on Revi- & & & 6) Government Code $§ 76104.6$ and 76104.7 (DNA Fund) \\
\hline sion of the Penal & & & 7) Government Code $\S 76000.10$ (Emergency Medical Air Trans. \\
\hline \multirow[t]{8}{*}{ Code 2021,81$)$} & & & Fee) \\
\hline & & & 8) Government Code $§ 76000.5$ (EMS Fund) \\
\hline & & & 9) Government Code $\S 70373$ (Conviction assessment) \\
\hline & & & 10) Vehicle Code $\S 42006$ (Night court assessment) \\
\hline & & & And if the driver misses court or any of the payments, \\
\hline & & & 11) Vehicle Code $\S 40508.6$ (DMV warrant/hold assessment fee) \\
\hline & & & 12) Vehicle Code $\S 40508.5$ (Fee for failing to appear) \\
\hline & & & $\begin{array}{l}\text { 13) Penal Code } \S 1214.1 \text { (Civil assessment for failure to appear/ } \\
\text { pay) }\end{array}$ \\
\hline
\end{tabular}

\section{2) Racial Disparities in Employment among People with Criminal Records}

(Western and Pettit 2000; 2005; Pager 2003; Pager et al. 2009)
Labor Com- Civilmissioner's Of- Criminal fice or Depart- (misment of Fair demeanor) Employment and Housing
1) Labor Code $\S 427(a)(1)$-an applicant for employment cannot be forced to disclose any information concerning an arrest or detention that did not result in conviction, or information concerning a referral to, and participation in, any pretrial or posttrial diversion program, or concerning a conviction that has been judicially dismissed or ordered sealed pursuant to law.

2) Penal Code $\S 1203.4,1203.4 a, 1203.425,1203.45$, and 1210.1 (judgement and execution of criminal procedure)

3) Labor Code $\S 427$ (c) - If a person violates this section, or Article 6 (commencing with Section 11140) of Chapter 1 of Title 1 of Part 4 of the Penal Code, the applicant may bring an action to recover from that person actual damages or two hundred dollars (\$200), whichever is greater, plus costs, and reasonable attorney's fees. An intentional violation of this section shall entitle the applicant to treble actual damages, or five hundred dollars (\$500), whichever is greater, plus costs, and reasonable attorney's fees. An intentional violation of this section is a misdemeanor punishable by a fine not to exceed five hundred dollars (\$500). [Emphasis Added]

4) Labor Code $\S 427$ (3)-An employer seeking disclosure of offense history under paragraph (2) shall provide the applicant with a list describing the specific offenses under Section $\mathbf{1 1 5 9 0}$ of the Health and Safety Code or Section $\mathbf{2 9 0}$ of the Penal Code for which disclosure is sought. [Emphasis Added]

5) Labor Code $\S 427$ (3)(j)-As used in this section, "pretrial or posttrial diversion program" means any program under Chapter 2.5 (commencing with Section 1000) or Chapter 2.7 (commencing with Section 1001) of Title 6 of Part 2 of the Penal Code, Section 13201 or 13352.5 of the Vehicle Code, Sections 626, 626.5, 654, or 725 of, or Article 20.5 (commencing with Section 790) of Chapter 2 of Part 1 of Division 2 of, the Welfare and Institutions Code, or any other program expressly authorized and described by statute as a diversion program. [Emphasis Added] 
Table 3. (continued)

\begin{tabular}{|c|c|c|c|}
\hline Social Fact & $\begin{array}{l}\text { Triggering } \\
\text { Agency }\end{array}$ & $\begin{array}{l}\text { Type of } \\
\text { Offense }\end{array}$ & Legal Capacity \\
\hline $\begin{array}{l}\text { 3) Racial Disparities } \\
\text { in Arrests and Con- } \\
\text { victions for Posses- } \\
\text { sion of Controlled } \\
\text { Substances } \\
\text { (Mooney et al. 2018; } \\
\text { Shannon et al. 2017) }\end{array}$ & $\begin{array}{l}\text { Local law en- } \\
\text { forcement; Cali- } \\
\text { fornia Depart- } \\
\text { ment of Justice }\end{array}$ & $\begin{array}{l}\text { Criminal } \\
\text { (felony) }\end{array}$ & $\begin{array}{l}\text { Health and Safety Code } \S 11350- \\
\text { (a) Except as otherwise provided in this division, every person } \\
\text { who possesses (1) any controlled substance specified in subdivi- } \\
\text { sion (b), (c), (e), or paragraph (1) of subdivision ( } f \text { ) of Section } \\
11054 \text {, specified in paragraph (14), (15), or (20) of subdivision (d) } \\
\text { of Section 11054, or specified in subdivision (b) or (c) of Section } \\
11055 \text {, or specified in subdivision (h) of Section 11056, or (2) any } \\
\text { controlled substance classified in Schedule III, IV, or V which is a } \\
\text { narcotic drug, unless upon the written prescription of a physician, } \\
\text { dentist, podiatrist, or veterinarian licensed to practice in this } \\
\text { state, shall be punished by imprisonment in a county jail for not } \\
\text { more than one year, except that such person shall instead be pun- } \\
\text { ished pursuant to subdivision (h) of Section } 1170 \text { of the Penal } \\
\text { Code if that person has one or more prior convictions for an of- } \\
\text { fense specified in clause (iv) of subparagraph (C) of paragraph ( } 2 \text { ) } \\
\text { of subdivision (e) of Section } 667 \text { of the Penal Code or for an of- } \\
\text { fense requiring registration pursuant to subdivision (c) of Section } \\
290 \text { of the Penal Code. [emphasis added] }\end{array}$ \\
\hline
\end{tabular}

(b) Except as otherwise provided in this division, whenever a person who possesses any of the controlled substances specified in subdivision (a), the judge may, in addition to any punishment provided for pursuant to subdivision (a), assess against that person a fine not to exceed seventy dollars $(\$ 70)$ with proceeds of this fine to be used in accordance with Section 1463.23 of the Penal Code. The court shall, however, take into consideration the defendant's ability to pay, and no defendant shall be denied probation because of his or her inability to pay the fine permitted under this subdivision. [Emphasis Added]

(c) Except in unusual cases in which it would not serve the interest of justice to do so, whenever a court grants probation pursuant to a felony conviction under this section, in addition to any other conditions of probation which may be imposed, the following conditions of probation shall be ordered:

(1) For a first offense under this section, a fine of at least one thousand dollars $(\$ 1,000)$ or community service.

(2) For a second or subsequent offense under this section, a fine of at least two thousand dollars $(\$ 2,000)$ or community service.

(3) If a defendant does not have the ability to pay the minimum fines specified in paragraphs (1) and (2), community service shall be ordered in lieu of the fine.

(continued) 
Table 3. (continued)

\begin{tabular}{l} 
Social Fact \\
\hline 4) Racial Disparities \\
in Foster Care \\
Placement
\end{tabular}

(Needell et al. 2003;

Child Welfare Information Gateway

2020)

Type of

Offense Legal Capacity

Agency Offense Legal Capacity

County Child Protective Services; California Department of Social Services

\section{Criminal} (felony and/ or misdemeanor)
Welfare \& Institutions Code $§ 300-$ A child who comes within any of the following descriptions is within the jurisdiction of the juvenile court which may adjudge that person to be a dependent child of the court:

(d) The child has been sexually abused, or there is a substantial risk that the child will be sexually abused, as defined in Section

$\mathbf{1 1 1 6 5 . 1}$ of the Penal Code, by his or her parent or guardian or a member of his or her household, or the parent or guardian has failed to adequately protect the child from sexual abuse when the parent or guardian knew or reasonably should have known that the child was in danger of sexual abuse. [Emphasis Added]

(g) The child has been left without any provision for support; physical custody of the child has been voluntarily surrendered pursuant to Section 1255.7 of the Health and Safety Code and the child has not been reclaimed within the 14-day period specified in subdivision ( $\mathrm{g}$ ) of that section; the child's parent has been incarcerated or institutionalized and cannot arrange for the care of the child; or a relative or other adult custodian with whom the child resides or has been left is unwilling or unable to provide care or support for the child, the whereabouts of the parent are unknown, and reasonable efforts to locate the parent have been unsuccessful. [Emphasis Added]

PEN § 270.1.(a)-A parent or guardian of a pupil of six years of age or more who is in kindergarten or any of grades 1 to 8, inclusive, and who is subject to compulsory full-time education or compulsory continuation education, whose child is a chronic truant as defined in Section $\mathbf{4 8 2 6 3 . 6}$ of the Education Code, who has failed to reasonably supervise and encourage the pupil's school attendance, and who has been offered language accessible support services to address the pupil's truancy, is guilty of a misdemeanor punishable by a fine not exceeding two thousand dollars $(\$ 2,000)$, or by imprisonment in a county jail not exceeding one year, or by both that fine and imprisonment. A parent or guardian guilty of a misdemeanor under this subdivision may participate in the deferred entry of judgment program defined in subdivision (b). [Emphasis Added]

PEN § 273 - If a parent of a minor child willfully omits, without lawful excuse, to furnish necessary clothing, food, shelter or medical attendance, or other remedial care for his or her child, he or she is guilty of a misdemeanor punishable by a fine not exceeding two thousand dollars $(\$ 2,000)$, or by imprisonment in the county jail not exceeding one year, or by both such fine and imprisonment.

PEN § 273d.-(a) Any person who willfully inflicts upon a child any cruel or inhuman corporal punishment or an injury resulting in a traumatic condition is guilty of a felony and shall be punished by imprisonment pursuant to subdivision (h) of Section 1170 for two, four, or six years, or in a county jail for not more than one year, by a fine of up to six thousand dollars $(\$ 6,000)$, or by both that imprisonment and fine. 
regardless of whether the case was dropped or dismissed (table 3, Exemplar \#2). This person would have recourse in civil court against the potential employer after filing a complaint with the California Labor Commissioner's Office or the Department of Fair Employment and Housing. The applicant could recover at least $\$ 200$ from the employer (a form of restitution for a civil offense). Furthermore, if the Labor Commissioner's Office or the Department of Fair Employment and Housing finds that the employer willfully engages in a pattern of such practices, a criminal misdemeanor charge could be brought against the employer, resulting in a possible $\$ 500$ fine. Moreover, the civilcriminal hybridity in this example reflects the cross-classification and activation of as many as five code sections: the Labor Code, the Penal Code, the Health and Safety Code, the Vehicle Code, and the Welfare and Institutions Code. Court fees would result in the activation of a sixth code section (the Government Code). Similar pathways of code section cross-activation exist in the case of driving on a suspended license (table 3, Exemplar \#1), possession of a controlled substance (table 3, Exemplar \#3), and child endangerment, abandonment, or chronic truancy (table 3, Exemplar \#4). The cross-activation of statutes with legal capacity for the power to punish may explain why the heatmap in figure 4 displays a similar degree of intensity for any given LFO attribute across different code sections outside the penal code.

\section{CONCLUSION AND IMPLICATIONS}

What is often thought of as the "typical" person with legal debt stands in stark contrast to the statutory framework that provides for the imposition of monetary sanctions across a sprawling array of offenses (from felonies to misdemeanors to infractions), adjudicative contexts (from the criminal to the civil and the hybrids in-between), and social circumstances (from the rich to the middle-class to the poor). Rather than approaching this as a gap between law-onthe-books and law-in-action (see Gould and Barclay 2012), we began our analysis by taking a step back to examine the prefiguring of "statutory inequality" (Friedman and Pattillo 2019) to produce racial disparity. In doing so, we reveal how the circuitry of law itself constructs the legal capacity for activating the inequality inscribed within monetary sanctioning statutes.

Findings from our work draw attention to how state power flows through this circuitry of LFO statutes embedded within and across legislative code sections, and comes to represent a form of structural inequality through legal capacity-with legal capacity being the necessary precursor for configuring the statutory inequality (Friedman and Pattillo 2019) that stands to produce racial and economic stratification when monetary sanctions are imposed. Features we found based on our analysis reveal that statutory inequality can also legally authorize prohibitions and limits on both the imposition and maximum amounts of LFOs; on the other hand, we also found statutes that legally authorized LFOs and enhanced the upper limits of LFO amounts, thus producing the legal capacity and legal risk to ratchet discretion upward to ever higher ceilings (see Lynch 2016).

Several points about our study are particularly important for researchers and policymakers. First, the application of monetary sanctions, in practice, remains an empirical matter, which we do not take up in this analysis. Our research here is limited to examining the observed statutes, but it does show that questions about the exercise of state power through the activation of legal capacity in practice and on the ground should be investigated, empirically, as law-in-action beyond that of penal codes. However, the implications and conclusions of our analysis here speak to the jurisdiction of LFOs and their statutory framework as a corpus, or body, of law, and as a political technology of power for producing proper subjects of control via legal debt and indebtedness (Bourdieu 2014; Foucault 1977; Simon 2013).

Second, the legal capacity we have identified and traced is more than just the amalgamation of 7,043 LFO statutes across twenty-nine legislative code sections in the state of California. State power and the power of law is its legal capacity to create a category of available subjects-subjects in their forms as individuals and populations, but also the legitimacy to govern various subjects or domains of life (Foucault 1970, 1977, 2007). This is where the social and the state, the civil and the criminal, meet 
(Beckett and Murakawa 2012; Coffee 1992). The legal capacity of LFO statutes produces the legal category of debtor-subjects and indebtedness as a legally specified and authorized mode of existence, which makes money and punishment, and people's money and time, the jurisdiction of the state (Pattillo and Kirk 2021).

Indebtedness may be a distinctive sociolegal category (Evans 2014; Graeber 2011; Hyman 2011; Mathiowetz 2007; O'Malley 2013; Walmsley 2019). ${ }^{7}$ As the criminological and sociological literature about being "on the run" and "having a warrant out" (Goffman 2009, 2015) shows, however, its logic and function as a legally legitimized disciplinary category, rendered in criminal law to facilitate surveillance beyond criminal law, is nothing new (see Brayne 2014; Kohler-Hausmann 2018; Murakawa and Beckett 2010). The main contribution of our study is to provide evidence for the contention that these disciplinary categories are structured, in part, by the sprawling presence of statutes concerning money and punishment in a corpus of control well beyond the Penal Code that forms the basis for legal capacity to punish and penalize. Our excavation of money and punishment in California law, which finds LFO statutes within and across all twenty-nine legislative code sections, suggests that the state power in this corpus depends on a legal dialectic between the criminal and the civil, as a way to enforce both contracts and control, in multiple domains of social life.

The findings of this study speak to the importance of examining monetary sanctions beyond binary civil-criminal boundaries in research and policy in order to reveal legal capacity wherever it may exist in the legal circuitry of social inequality. The implication is that this circuitry leads to the legal structuration of racial disparity, divestment, and dispossession when the legal capacity created by LFO statutes as they are inscribed, yet unevenly distributed across civil and criminal codes, is ac- tivated by the state. It is therefore notable that the statute governing the Penal Code Revision Committee's creation, purpose, and powers specifically delineates the committee's authority to make recommendations to adjust the terms of criminal sentences under state law, ${ }^{8}$ and that it may do so considering "empirically significant disparities between individuals convicted of an offense and individuals convicted of other similar offenses" as one of the five factors explicitly listed. ${ }^{9}$ Yet the statutory text remains silent on the overt question of race and societal racial inequality, including racially selective criminal justice surveillance, arrest, and enforcement as a salient and already empirically evident fact of life in the Golden State. Indeed, California Governor Gavin Newsom's opening remarks at the Penal Code Revision Committee's first public hearing in January 2020 took no time to read between the lines of law to express, in no uncertain terms, the executive intent of the governing statute. ${ }^{10}$ As the committee reports, "Governor Newsom acknowledged many of these issues when he addressed the Committee, noting 'jaw-dropping' racial disparities in sentencing across the state. He encouraged us to address the 'deep racial overlays and the deep socioeconomic overlays that often determine the fate of so many in our system'" (Committee on Revision of the Penal Code 2021, 5). Although the committee is poised to make consequential inroads in reducing racial inequality in criminal sentencing, less is known about how the legal capacity to produce racial disparities will be ameliorated within those domains of life falling under the civil and, no less, often overlapping civilcriminal jurisdictions of law. Within and, crucially, beyond the Penal Code, it will take reform, revision, and excision rather than recodification of both the form and the compositional substance of monetary sanctioning statutes to make them less a part, or no part, of the sprawling corpus of California law.

7. Dean Mathiowetz (2007) engages, in particular, the distinctive human subjectivities that inure to historical transformations in "the juridical subject of 'interest'."

8. CA Govt Code § 8290.5 (2020).

9. CA Govt Code $\S 8290.5[b][5]$ (2020).

10. CA Govt Code $§ 8290.5$ (2020). 
With the inauguration of the Penal Code Revision Committee in 2020, California has followed Texas's suit, albeit in a manner of limited revision, and possible excisions, of statutes from the state's Penal Code. Texas undertook the legal census of its corpus of law from the starting point of problems identified in the statutory framework that might exist for monetary sanctions. By contrast, the effort to take stock, rationalize, and revise but one of California's twenty-nine code sections - the Penal Code-arrived by the end of its first year where Texas began (see Bing, Pettit, and Slavinski 2022, this volume; Dahaghi 2017): the need to rein in the legal capacity to impose LFOs as punishments with racially disparate effects within as well as beyond the Penal Code. The California Committee on Revision of the Penal Code's very first recommendation was to "eliminate incarceration and reduce fines and fees for certain traffic offenses" (2021, 14; see Exemplar \#1 in table 3).

As codification rather than common law states, Texas and California have taken their first steps to rein in the legal capacity for LFOs (Committee on Revision of the Penal Code 2021; State of Texas 2014). Less is known, however, about the efforts of New York, the only other fully codified U.S. state, to approach something akin to the legal census necessary as a first step in mapping the circuitry of power that stands to produce racial disparities in the imposition of LFOs and legal indebtedness. The implications of this work for the other forty-seven states, where the locus of inequality in the law of LFOs may not be codified as such but nevertheless operates in powerful ways to produce racial disparities as a social fact of monetary sanctions, requires the analyst and policymaker alike to reckon with the entire body of state law, beginning with the first-order task of conducting a legal census that maps the totality of legal capacity and, in turn, has the potential to reveal the full power of the state to punish.

Former California Governor Jerry Brown put it succinctly to the California Penal Code Revision Committee in 2020, "die by fire or you can die by ice"-meaning that the committee can be too timid, but at the same time cannot go too far in embarking on what Brown called "virgin territory" to revise the state's Penal Code (Committee on Revision of the Penal Code 2020). By his last term as governor, Brown's critique of California's Penal Code was clear; he stated that "the penal code, littered with thousands of provisions, had become utterly counterproductive and a far cry from a fair and effective system of criminal justice" (Brown 2018). As the thirty-fourth (1975-1983) and thirty-ninth (2011-2019) governor of California, Brown said in his latest testimony before the state's Penal Code Revision Committee that "the California Penal Code 2020 is a monster" and characterized it as "a giant ball" and "a cornucopia of bad ideas that you can pluck at will as you wander through the provisions" (Committee on Revision of the Penal Code 2020). By all accounts put forth before the committee over a full year of hearings and testimony during 2020, the heart of the problem with California's Penal Code had become decidedly conspicuous: the proliferation of criminalizing statutes and the sheer scale of legal capacity for the state to punish, and not least, according to Brown, who concluded his remarks with a commentary on the fate of ever-expanding state capacity to police, punish, and imprison, thus, "if you build it, they will come" (Committee on Revision of the Penal Code 2020).

The legacy of legal codification in California can be observed today in the decisive force for lawmaking outside the judiciary and the legislature: "the people," who invoke direct democracy to forge both new legal capacities for, as well as to constrict, state power through voter-initiated ballot propositions and referenda (Barker 2006, 2009; Miller 2013, 2016). Recently, Californians exercised such power in 2018 through their repeal of Senate Bill 10,11 which the legislature passed to abolish cash bail in the state's criminal justice system; under Proposition 25, 56.4 percent of California voters elected to repeal the legislature's abolition of cash bail by referendum, thus recodifying money and punishment into California 
law. ${ }^{12}$ In that same election, however, California voters approved Proposition $17,{ }^{13}$ which extended voting rights to those who have served their prison sentences but remain on state parole, thereby excising the legal capacity to constrain civic life beyond the prison walls for people on parole, many of whom are likely to have outstanding LFOs and carry the burdens of legal debt (Uggen, Larson, and Shannon 2016).

Ultimately, the unexplored terrains of law necessitate examining legal financial obligations as embedded in both criminal and civil codes, and recognizing LFOs as forms of punishment, regardless of where they may be located in the larger corpus of law. The recogni- tion that LFOs function as sanctions, by way of obligation, leads to a reconceptualization of punishment itself as a legal capacity, within, but also beyond, the Penal Code. Boaventura de Sousa Santos observes, "by constantly changing colours according to certain biological rules, the chameleon is truly not an animal but rather a network of animals - as much as law is a network of legal orders" $(1987,299)$. The constantly changing colors of money and punishment, as they circulate within and beyond the Penal Code, and their evolving classification and reclassifications of legal jurisdiction across criminal and civil codes, render legal financial obligations more or less visible as monetary sanctions in the corpus of California law.

12. California Proposition 25, "Referendum on Law that Replaced Money Bail with System Based on Public Safety and Flight Risk," November 3, 2020 (failed).

13. Proposition 17, “Restores Right to Vote after Completion of Prison Term,” November 3, 2020 (constitutional amendment). 
Table A1. Codebook: Variable List, Abbreviations, and Descriptions

CODER-coder

First and last name initials of research assistant who coded this section.

DATE CODED-date

Date of coding session and therefore the date of the online version of California law coded.

STATE-state

Two-letter abbreviation of the state (CA).

CODE-codesec

Abbreviation for one of California's 29 Code sections containing particular reference to monetary sanctions imposition or administration.

STATUTE NUMBER-statute_n

Number that identifies each separate statute referencing monetary sanctions imposition or administration.

${ }^{*}$ Note: Enter each statute number separately in its own row.

ADDITIONAL STATUTORY CITATIONS-statute_n2

As applicable, enter any additional bibliographic information on how to locate this law.

TITLE-title

If applicable, enter the title of the statute.

YEAR ENACTED-yr_enact

Initial year that a particular law or statute was implemented, if known. Enter Year (NUMERICAL VALUE) or NA if Unknown.

LAST AMENDED-yr_amend

Last year in which a particular law or statute was amended, if known. Enter Year (NUMERICAL VALUE) or NA if Unknown..

FULL STATUTE TEXT-text_full

Verbatim text of the observed law or statute. Copy and paste TEXT from code.

SUMMARY-text_summ

Brief summary statement of the relevance of this law for the imposition or administration of monetary sanctions, written by the researcher. Aim for less than two sentences when possible.

${ }^{*}$ Note: Indication of a question or a flag that a statute repeats or cross references another statute was entered into this field during the data cleaning process.

FINE-FEE-finefee

Does this law concern a particular fine AND/OR fee (excluding surcharges, financing charges, interest)? $\mathrm{YES}=1$ or $\mathrm{NO}=0$.

*Note: FINE-FEE should be coded as YES=1 whether it imposes or prohibits the imposition of a fine and/ or fee.

FINE-fine

Does this law define a particular FINE (excluding surcharges, financing charges, interest)? YES=1 or $\mathrm{NO}=0$.

FEE-fee

Does this law define a particular FEE (excluding surcharges, financing charges, interest)? YES=1 or $\mathrm{NO}=0$.

*Note: Statutes concerning the payment of attorney fees in *civil" litigation (i.e., to plaintiff's attorneys) should not be coded.

*Note: FEE should be coded YES $=1$, however, for statutes that may combine * ${ }^{*}$ riminal ${ }^{*}$ fees and any fees in the civil context. 
Table A1. (continued)

PUBLIC ATTY-atty

Does this law require those sanctioned to pay any amount for the provision of a public attorney for themselves or for others? $\mathrm{YES}=1$ or $\mathrm{NO}=0$.

NONPAY INCAR-incarc_nonpay

Does this law (a) provide for the detention or incarceration of those who do not pay monetary sanctions for any reason or (b) enable the application of credit to legal debt for time incarcerated (sit it out)? $\mathrm{YES}=1$ or $\mathrm{NO}=0$.

COMM SERVICE-commserv

Does this law provide for credits toward monetary sanctions for community service work? YES $=1$ or $\mathrm{NO}=0$.

VOTING-vote

Does this law curtail the voting rights of those with unpaid monetary sanctions? $Y E S=1, N O=0$, or PROVISIONAL.

JUVENILE-juv

Does this law have special provisions for those under the age of 18 ? $\mathrm{YES}=1$ or $\mathrm{NO}=0$.

FINANCING INTEREST SURCHARGE-interest

Does this law allow for interest fees over and above the imposed monetary sanction? YES $=1$ or $N O=0$.

SURCHARGE-surcharge

Does this law impose particular surcharges over and above the imposed monetary sanction? YES $=1$ or $\mathrm{NO}=0$.

*Note: surcharge is a charge in addition to the usual amount paid for something, or to the amount already paid (i.e., a processing or handling fee).

COLLECTION FEE-collectfee

Does this law allow for the collection of financing or processing fees over and above the imposed monetary sanction? $\mathrm{YES}=1$ or $\mathrm{NO}=0$.

PERPAYMENT FEE-perpayfee

Does this law allow for jurisdictions to charge per payment fees each time a person makes a payment over and above the imposed monetary sanction? $\mathrm{YES}=1$ or $\mathrm{NO}=0$.

PRIVATE COLLECTION-privcollect

Does this law enable private agencies to administer or collect monetary sanctions? YES $=1$ or $N O=0$.

CRIMINAL CATEGORIZATION-crim

Does this law classify a particular violation as criminal (as opposed to civil)? YES $=1$ or $N O=0$.

WARRANTS SUMMONS HEARINGS-warrant

Does this law allow for the issuance of warrants or summons, or require hearings for non-payment, extension, or financing of monetary sanctions? $\mathrm{YES}=1$ or $\mathrm{NO}=0$.

\section{LOSS OF LICENSE-license}

Does this law allow or require the loss of a driver's license for non-payment or delayed payment of monetary sanctions? $\mathrm{YES}=1$ or $\mathrm{NO}=0$.

MANDATORY MIN SANCTION-mandmin

Does this law mandate the imposition of a monetary sanction (as opposed to allowing officials to use discretion in its application)? $\mathrm{YES}=1$ or $\mathrm{NO}=0$.

MINIMUM LFO AMOUNT-amount_min

If indicated, the minimum dollar amount of the monetary sanction. Enter in NUMERICAL VALUE. 
Table A1. (continued)

MAXIMUM LFO AMOUNT-amount_max

If indicated, enter the maximum dollar amount of the monetary sanction. Enter in NUMERICAL

VALUE.

OTHER LFO AMOUNT-amount_other

If indicated, any other dollar amount of monetary sanction. Enter in NUMERICAL VALUE.

LFO FORMULA/CALCULATION-TYPE-formula

Does the statute specify a formula for calculating an LFO? YES $=1$ or $\mathrm{NO}=0$.

LFO COMBINED W/ INCARCERATION-TYPE-incarc_Ifo

Does the statute provide for various ways that incarceration (either in jail or prison) be combined with or substituted for payment of LFOs? YES $=1$ or $\mathrm{NO}=0$.

LFO ENHANCEMENT-TYPE-enhance

Does the statute specify ways that LFO may be enhanced (i.e. for certain kinds of offenses)? YES=1 or $\mathrm{NO}=0$.

IF ENHANCEMENT-TYPE, ENHANCED MINIMUM LFO AMOUNT-enhance_min

If indicated, the minimum dollar amount of the *enhanced* monetary sanction. Enter NUMERICAL VALUE.

IF ENHANCEMENT-TYPE, ENHANCED MAXIMUM LFO AMOUNT-enhance_max

If indicated, the maximum dollar amount of the *enhanced* monetary sanction. Enter NUMERICAL VALUE.

IF ENHANCEMENT-TYPE, ENHANCED OTHER LFO AMOUNT-enhance_other

If indicated, any other dollar amount of the *enhanced* monetary sanction. Enter NUMERICAL VALUE.

FELONY-felony

If indicated, is the monetary sanction applied for a felony crime? $\mathrm{YES}=1$ or $\mathrm{NO}=0$.

MISDEMEANOR (NON-TRAFFIC)-misd_nontraff

If indicated, is the monetary sanction applied for a non-traffic misdemeanor crime? YES $=1$ or NO=0.

MISDEMEANOR (TRAFFIC)-misd_traff

If indicated, is the monetary sanction applied for a traffic misdemeanor crime? $\mathrm{YES}=1$ or $\mathrm{NO}=0$.

PROHIBITS LFO-prohibits

Does the statute *prohibit* the assessment of any kind of LFO? YES $=1$ or NO=0.

VICTIM RESTITUTION-victimrest

Does the statute impose a LFO for the purpose of victim restitution or payment? YES $=1$ or NO=0.

Source: Authors' tabulation compilation based on the Multi-State Monetary Sanctions Study research design, as implemented in California, for reviewing law and policy concerning LFOs across all state study field sites (Harris et al. 2017: X; Harris et al. this issue).

Note: Date of Final Codebook, May 27, 2016.

\section{REFERENCES}

Appel, Hannah, Sa Whitley, and Caitlin Kline. 2019.

The Power of Debt: Identity and Collective Action in the Age of Finance. Los Angeles: University of California Institute on Inequality and Democracy, the Shuttleworth Foundation, and the Debt Collective.

Bannon, Alicia, Mitali Nagrecha, and Rebeka Diller. 2010. Criminal Justice Debt: A Barrier to Reentry. New York: Brennan Center for Justice. 
Barker, Vanessa. 2006. “The Politics of Punishing: Building a State Governance Theory of American Imprisonment Variation." Punishment \& Society 8(1): 5-32.

- 2009. The Politics of Imprisonment: How the Democratic Process Shapes the Way America Punishes Offenders. New York: Oxford University Press.

Beckett, Katherine, and Naomi Murakawa. 2012. “Mapping the Shadow Carceral State: Toward an Institutionally Capacious Approach to Punishment." Theoretical Criminology 16(2): 221-44.

Bing, Lindsay, Becky Pettit, and Ilya Slavinski. 2022. “Incomparable Punishments: How Economic Inequality Contributes to the Disparate Impact of Legal Fines and Fees." RSF: The Russell Sage Foundation Journal of the Social Sciences 8(2): 118-36. DOI: https://doi.org/10.7758/RSF 2022.8.2.06.

Bourdieu, Pierre. 2014. On the State: Lectures at the Collège de France, 1989-1992. Malden, Mass.: Polity Press.

Brayne, Sarah. 2014. “Surveillance and System Avoidance: Criminal Justice Contact and Institutional Attachment." American Sociological Review 79(3): 367-91.

Brown, Edmund G., Jr. 2018. "State of the State Address." Sacramento: California Governor's Library. Accessed March 8, 2021. https://governors.library .ca.gov/addresses/s_39-JBrown7.html.

California Legislative Information (CLI). 2021. Sacramento: State of California Office of Legislative Counsel. https://leginfo.legislature.ca.gov/faces /codes.xhtml. Accessed September 1, 2021.

Child Welfare Information Gateway. 2020. Foster Care Statistics 2018. Washington: U.S. Department of Health and Human Services, Administration for Children and Families, Children's Bureau. Accessed March 9, 2021. https://www.child welfare.gov/pubPDFs/foster.pdf.

Coffee, John C., Jr. 1992. “Paradigms Lost: The Blurring of the Criminal and Civil Law-and What Can Be Done About It." Yale Law Journal 101(8): 1875-894.

Collateral Consequences Resource Center. 2019. "California Compilation of Collateral Consequences." Accessed August 6, 2021. http:// california.ccresourcecenter.org/consequence -search.

Committee on Revision of the Penal Code. 2020. Video Archives: Meeting, September 17, 2020.
1:24:14-1:24:50. Sacramento: California Law Revision Commission. Accessed July 21, 2021. http://www.clrc.ca.gov/CRPC/Meetings/Video .html.

- 2021. Annual Report and Recommendations, 2020. Sacramento: California Law Revision Commission. Accessed March 8, 2021. http://www .clrc.ca.gov/CRPC/Pub/Reports/CRPC_AR2020 .pdf.

Dahaghi, Kevin. 2017. "Punishment and Penal Activity: The Expansion of Legal Fines and Fees in Texas from 1985-2015." M.A. thesis, University of Texas at Austin.

Evans, Douglas N. 2014. The Debt Penalty: Exposing the Financial Barriers of Offender Reintegration. New York: John Jay College of Criminal Justice.

Fernandes, April D., Brittany Friedman, and Gabriela Kirk. 2022. “The 'Damaged' State vs. the 'Willful' Nonpayer: Constructing Damage, Harm, and Willfulness Through Pay-to-Stay Lawsuits," RSF: Russell Sage Foundation Journal of the Social Sciences 8(1): 82-105. DOI: https://doi.org/10.7758 /RSF.2022.8.1.04.

Field, David Dudley. 1890. “Codification." American Law Review 20: 1.

Foucault, Michel. 1970. The Order of Things: An Archeology of the Human Sciences, 2nd ed. New York: Routledge. . 1977. Discipline \& Punish: The Birth of the Prison, translated by Alan Sheridan. New York: Vintage Books.

- 2007. Security, Territory, Population: Lectures at the Collège de France, 1977-78. New York: Springer.

Friedman, Brittany, and Mary Pattillo. 2019. “Statutory Inequality: The Logics of Monetary Sanctions in State Law." RSF: The Russell Sage Foundation Journal of the Social Sciences 5(10): 17396. DOI: https://doi.org/10.7758/RSF.2019.5.1.08.

Garland, David. 1990. Punishment and Modern Society. Chicago: University of Chicago Press.

Goffman, Alice. 2009. “On the Run: Wanted Men in a Philadelphia Ghetto." American Sociological Review 74(3): 339-57.

- 2015. On the Run: Fugitive Life in an American City. New York: Picador.

Gordon, Margaret A., and Daniel Glaser. 1991. “The Use and Effects of Financial Penalties in Municipal Courts." Criminology 29(4): 651-76.

Gould, Jon B., and Scott Barclay. 2012. "Mind the Gap: The Place of Gap Studies in Sociolegal 
Scholarship." Annual Review of Law and Social Science 8(1): 323-35.

Graeber, David. 2011. Debt: The First 5,000 Years. Brookeville, N.Y.: Melville House.

Harris, Alexes. 2016. A Pound of Flesh: Monetary

Sanctions for the Poor. New York: Russell Sage Foundation.

Harris, Alexes, Heather Evans, and Katherine Beckett. 2010. “Drawing Blood from Stones: Legal Debt and Social Inequality in the Contemporary United States." American Journal of Sociology 115(6): 1753-799.

_. 2011. "Courtesy Stigma and Monetary Sanctions: Toward a Socio-Cultural Theory of Punishment." American Sociological Review 76(2): 1-31.

Harris, Alexes, Beth Huebner, Karin Martin. Mary Pattillo, Becky Pettit, Sarah Shanon, Bryan L. Sykes. Chris Uggen, and April Fernandes. 2017. "Monetary Sanctions in the Criminal Justice System: A Review of Law and Policy in California, Georgia, Illinois, Minnesota, Missouri, New York, North Carolina, Texas, and Washington." Report. Accessed September 1, 2021. http://www .monetarysanctions.org/index.php/2017/04/20 /research-team-tracks-complex-web-of-monetary -sanctions-in-9-states/.

Harris, Alexes, Mary Pattillo, and Bryan L. Sykes. 2022. "Studying the System of Monetary Sanctions." RSF: The Russell Sage Foundation Journal of the Social Sciences 8(1): 1-33. DOI: https://doi .org/10.7758/RSF.2022.8.1.01.

Huebner, Beth M., and Andrea Giuffre. 2022. "Reinforcing the Web of Municipal Courts: Evidence and Implications Post-Ferguson." RSF: The Russell Sage Foundation Journal of the Social Sciences 8(1): 108-27. DOI: https://doi.org/10.7758 /RSF.2022.8.1.05

Hyman, Louis. 2011. Debtor Nation: The History of America in Red Ink. Princeton, N.J.: Princeton University Press.

Kaiser, Joshua. 2016. "Revealing the Hidden Sentence: How to Add Transparency, Legitimacy, and Purpose to Collateral Punishment Policy." Harvard Law \& Policy Review 10(1): 123-83.

Kohler-Hausmann, Issa. 2018. Misdemeanorland: Criminal Courts and Social Control in an Age of Broken Windows Policing. Princeton, N.J.: Princeton University Press.

Lynch, Mona. 2016. Hard Bargains: The Coercive Power of Drug Laws in Federal Court. New York: Russell Sage Foundation.
Mann, Kenneth. 1980. "Punitive Civil Sanctions: The Middleground Between Criminal and Civil Law." Yale Law Journal 101(8): 1795-873.

Mathiowetz, Dean. 2007. “The Juridical Subject of 'Interest'." Political Theory 35(4): 468-93.

Miller, Lisa L. 2013. “Power to the People: Violent Victimization, Inequality and Democratic Politics," Theoretical Criminology 17(3): 283-313.

- 2016. The Myth of Mob Rule: Violent Crime and Democratic Politics. New York: Oxford University Press.

Mooney, Alyssa, Eric Giannella, M. Maria Glymour, Torsten B. Neilands, Meghan D. Morris, Jacqueline Tulsky, and May Sudhinaraset. 2018. “Racial/ Ethnic Disparities in Arrests for Drug Possession After California Proposition 47, 2011-2016." American Journal of Public Health 108(8): 987-93.

Murakawa, Naomi, and Katherine Beckett. 2010. "The Penology of Racial Innocence: The Erasure of Racism in the Study and Practice of Punishment." Law \& Society Review 44(3-4): 695-730.

Natapoff, Alexandra. 2018. Punishment Without Crime: How Our Massive Misdemeanor System Traps the Innocent and Makes America More Unequal. New York: Basic Books.

National Clean Slate Clearinghouse. 2015-2021. Washington: U.S. Department of Labor and U.S. Department of Justice. Accessed March 8, 2021. https://cleanslateclearinghouse.org/about.

National Inventory of Collateral Consequences of Conviction. 2020. NICCC Website. Washington: U.S. Department of Justice, National Reentry Resource Center. Accessed March 8, 2021. https:// niccc.nationalreentryresourcecenter.org.

Needell, Barbara, M. Alan Brookhart, and Soon Lee. 2003. "Black Children and Foster Care Placement in California." Children and Youth Services Review 25(5-6): 393-408.

O'Malley, Pat. 2013. "Monetized Justice: Money and Punishment in Consumer Societies." In The SAGE Handbook of Punishment and Society, edited by Jonathan Simon and Richard Sparks. London: Sage Publications.

Pager, Devah. 2003. “The Mark of a Criminal Record." American Journal of Sociology 108(5): 93775.

Pager, Devah, Bart Bonikowski, and Bruce Western. 2009. “Discrimination in a Low-Wage Labor Market: A Field Experiment." American Sociological Review 74(5): 777-99.

Page, Joshua, Victoria Piehowski, and Joe Soss. 
2019. "A Debt of Care: Commercial Bail and the Gendered Logic of Criminal Justice Predation." RSF: The Russell Sage Foundation Journal of the Social Sciences 5(1): 150-72. DOI: https://doi.org /10.7758/RSF.2019.5.1.07.

Pattillo, Mary, and Gabriella Kirk. 2021. “Layaway Freedom: Coercive Financialization in the Criminal Legal System." American Journal of Sociology 126(4): 889-930.

Pettit, Becky. 2012. Invisible Men: Mass Incarceration and the Myth of Black Progress. New York: Russell Sage Foundation.

Pettit, Becky, and Bryan Sykes. 2015. “Civil Rights Legislation and Legalized Exclusion: Mass Incarceration and the Masking of Inequality." Sociological Forum 30(S1): 589-611.

Quinn, Sarah L. 2017. “'The Miracles of Bookkeeping': How Budget Politics Link Fiscal Policies and Financial Markets." American Journal of Sociology 123(1): 48-85.

- 2019. American Bonds: How Credit Markets

Shaped a Nation. Princeton, N.J.: Princeton University Press.

Rabinowitz, Mikaela, Robert Weisberg, and Lauren McQueen Pearce. 2019. "The California Criminal Justice Data Gap." Palo Alto, Calif.: Stanford Law School.

Shannon, Sarah K.S., Christopher Uggen, Jason Schnittker, Melissa Thompson, Sara Wakefield, and Michael Massoglia. 2017. "The Growth, Scope, and Spatial Distribution of People with Felony Records in the United States, 1948-2010." Demography 54(5): 1795-818.

Simon, Jonathan. 2013. "Punishment and the Political Technologies of the Body." In The SAGE Handbook of Punishment and Society 60, edited by Jonathan Simon and Richard Sparks. London: Sage Publications.

Smith, Tyler, Kristina J. Thompson, and Michele Cadigan. 2022. "Sensemaking in the Legal System: A Comparative Case Study of Changes to Monetary Sanction Laws." RSF: The Russell Sage Foundation Journal of the Social Sciences 8(1): 63-81. DOI: https://doi.org/10.7758/RSF.2022 8.1.03.

de Sousa Santos, Boaventura. 1987. “Law: A Map of Misreading. Toward a Postmodern Conception of Law." Journal of Law and Society 14(3): 279-302.

State of Texas Office of Court Administration (State of Texas). 2014. Study of the Necessity of Certain
Court Costs and Fees in Texas, as Directed by Senate Bill 1908, 83rd Legislature. Austin: Texas Judicial Council. Accessed March 8, 2021. https://www.txcourts.gov/media/495634 /SB1908-Report-FINAL.pdf.

Sykes, Bryan L., Meghan Ballard, Andrea Giuffre, Rebecca Goodsell, Daniela Kaiser, Vicente Celestino Mata, and Justin Sola. 2022. "Robbing Peter to Pay Paul: Public Assistance, Monetary Sanctions, and Financial Double-Dealing in America." RSF: The Russell Sage Foundation Journal of the Social Sciences 8(1): 148-78. DOI: https://doi.org /10.7758/RSF.2022.8.1.07.

Uggen, Christopher, Ryan P. Larson, and Sarah K.S. Shannon. 2016. “6 Million Lost Voters: StateLevel Estimates of Felony Disenfranchisement," Washington: The Sentencing Project. Accessed March 9, 2021. https://www.sentencingproject .org/wp-content/uploads/2016/10/6-Million -Lost-Voters.pdf.

U.S. Census Bureau (Census Bureau). 2021. “2020 Population and Housing State Data," 2020 Census Redistricting Data (Public Law 94-171) Summary File. Washington: U.S. Department of Commerce. Accessed September 1, 2021. https:// www.census.gov/library/visualizations/inter active/2020-population-and-housing-state -data.html.

U.S. Department of Justice, Civil Rights Division (DOJ). 2015. Investigation of the Ferguson Police Department. Washington: Government Printing Office.

Walmsley, Dillon. 2019. “Neoliberalism, Mass Incarceration, and the US Debt-Criminal Justice Complex." Critical Social Policy 39(2): 248-67.

Ward, Geoff. 2015. "The Slow Violence of State Organized Race Crime." Theoretical Criminology 19(3): 299-314.

Western, Bruce, and Becky Pettit. 2000. "Incarceration and Racial Inequality in Men's Employment." Industrial and Labor Relations Review 54(1): 3-16.

- 2005. “Black-White Wage Inequality, Employment Rates, and Incarceration." American Journal of Sociology 111(2): 553-78.

Westlaw Next Online Legal Research (Westlaw Next). 2021. "California Statutes \& Court Rules." Eagan, M.N.: Thomson Reuters. https://legal .thomsonreuters.com/en/products/westlaw. Accessed September 1, 2021. 